\title{
Javanese Cultural Values of the Yogyakarta Palace in the Film 'Marak: Mresani Panji Sekar'
}

\author{
Yulian Dinihari*), \\ Universitas Indraprasta PGRI \\ Zuriyati, \\ Universitas Negeri Jakarta \\ Ninuk Lustyantie, \\ Universitas Negeri Jakarta \\ *) Correspondences author: Jalan Kebagusan III No. 78CD, Jakarta Selatan, 12250; Indonesia; \\ e-mail: yuliandini07@gmail.com
}

\begin{abstract}
Film is one of the effective and popular media in cultural learning, both local and foreign cultures. The film that is used as the object of research by the researcher is the film 'Marak: Mresani Panji Sekar"'. This film becomes an interesting study material because it explains the Javanese culture of the courtiers of the Yogyakarta Palace who will focus more on culture in the film. This research uses descriptive qualitative research method. Analyzing cultural values by means of observation and study of documents in films in an effort to gain an overview and understanding of what is being studied. The values obtained are in the form of many values contained in it, namely the values of honor, trust, politeness, responsibility, and art. Describe the Javanese values of the Yogyakarta Palace which are shown in the film 'Marak: Mresani Panji Sekar' and reveal and understand the meaning contained in these traditional values.
\end{abstract}

Keywords: Film, Values, Javanese Cultural

Article History: Received: 20/10/2021; Revised: 23/11/2021; Accepted: 04/12/2021; Published: 30/12/2021

How to Cite (MLA $7^{\text {th }}$ ): Dinihari, Yulian, Zuriyati, and Ninuk Lustyantie. "Javanese Cultural Values of the Yogyakarta Palace in the Film 'Marak: Mresani Panji Sekar'." Hortatori Jurnal Pendidikan Bahasa dan Sastra Indonesia 5.2 (2021): 178187. Print/Online. Copyrights Holder: Yulian Dinihari, Zuriyati, Ninuk Lustyantie. First Publication: Hortatori Jurnal Pendidikan Bahasa dan Sastra Indonesia (2017).

\section{Pendahuluan}

Sastra sebagai hasil karya seni manusia berupa lisan maupun tulisan yang mempunyai makna atau keindahan tertentu. Kesusastraan hadir sebagai bagian eksistensi dari keberadaan manusia. Pada mulanya semua sastra bersifat religius, kemudian berdasarkan perkembangannya menjadi media ekspresi pengalaman estetik dan mistik dimana manusia ketika berhadapan dengan kekuatan "alam" (natural) dan "ilahi"(supernatural) (Febriyanti et al.). Dalam sastra terkandung eksplorasi mengenai kebenaran kemanusiaan, adat istiadat, agama, kebudayaan, dan sebagainya. (Tindaon). Pembelajaran sastra dianggap penting karena pembelajaran sastra dapat membantu pembentukan watak. Dalam nilai pembelajaran sastra ada dua tuntutan yang dapat diungkapkan sehubungan dengan pembentukan watak ini. Pertama, pembelajaran sastra hendaknya mampu membina perasaan yang lebih tajam. Seseorang yang telah banyak mendalami berbagai karya sastra biasanya memiliki perasaan yang lebih peka untuk menunjuk hal mana yang bernilai dan mana yang tak bernilai. Tuntutan kedua, bahwa pembelajaran sastra hendaknya dapat memberikan bantuan dalam usaha mengembangkan berbagai kualitas kepribadian siswa yang antara lain meliputi ketekunan, kepandaian, pengimajian, dan penciptaan (Tindaon).

Menurut Teeuw sastra tidak dapat diteliti dan dipahami secara ilmiah tanpa mengikutsertakan kemasyarakatannya yaitu tanpa memandangi sebagai tindak komunikasi. Hal tersebut berarti bahwa sastra 
bukanlah komunikasi yang biasa dan mempunyai banyak segi yang aneh dan luar biasa jika dibandingkan dengan tindak komunikasi lain, tetapi pemahaman gejala ini yang sesuai dan tepat tidak mungkin tanpa memperhatikan aspek komunikatifnya atau dengan istilah lain tanpa mendekati sastra sebagai tanda, sign atau gejala semiotika (Teeuw. A). Sastra tidak bisa berjalan jika tidak memiliki Bahasa, maka peran linguistik sangat ditekankan dalam sastra. Sebagai karya sastra yang bermediakan bahasa, karya sastra memiliki bahasa yang sangat berbeda dengan bahasa baik yang digunakan sehari-hari maupun bahasa karya ilmiah (Mirnawati).

Salah satu yang menjadi simbol keberadaan suatu komunitas adalah bahasa. Bahasa merupakan salah satu penanda di antara beberapa penanda komunitas (dalam hal ini etnis) yang sangat penting (Pradopo). Bahasa merupakan induk dari sebuah ilmu. Tempat bahasa dalam sosial sangat penting, bahasa merupakan bagian dari perubahan. Awalnya sastra hanya dikelompokkan menjadi satu jenis saja yakni cerita. Seiring dengan berkembangnya seni sastra, muncul beberapa jenis baru. Bahkan pengertian seni sastra juga mulai ditentukan definisinya, supaya jelas batas mana seni sastra dan mana yang bukan. Sastra dibagi menjadi tiga bagian, yaitu Puisi, Prosa, dan Drama. Media film dalam pembelajaran sastra digunakan untuk mempermudah pembelajar sastra khususnya mahasiswa, mengapresiasikan, menginterpretasikan makna dalam karya sastra. Mahasiswa selaku pembelajar sastra dapat mendeskripsikan interpretasi mereka terhadap karya sastra dengan mudah dan benar, melalui ekspresi tokoh dalam film, penyajian pelataran, teknik suara, pencahayaan, dan properti-properti lain yang digunakan dalam film,

Film adalah lembaran tipis, bening, mudah lentur yang dilapisi dengan lapisan antihalo, dipergunakan untuk keperluan fotografi (Kridalaksana). Dimaksudkan di sini adalah bentuk dari film itu sendiri, ketika kita melihat benda berupa fil maka akan membentuk hal yang demikian. Film memiliki sifat lihat dengan (audio-visual) dan dapat mencapai khalayak yang banyak. Melalui media tersebut, para pembelajar dan peneliti sastra diharapkan akan menerapkan teori-teori kajian sastra dengan mudah sehingga hasil yang diharapkan sesuai dengan tujuan akan dapat dicapai dengan baik. Film dibentuk dengan alur cerita, seperti halnya prosa dan drama.

Keberadaan film dalam masyarakat dianggap mempunyai nilai yang tinggi dibandingkan dengan media komunikasi lain. Penilaian tersebut dapat kita lihat dari tampilan kualitas gambar dari film itu sendiri. Film di Indonesia menjadi bagian yang tidak terpisahkan dari kebiasaan hidup borjuis bagi masyarakat modern terutama Jakarta. Tidak heran jika orang-orang akan dengan sengaja menonton film pilihannya di bioskop-bioskop ternama. Sebagai sebuah tayangan yang menghibur, film banyak dinikmati para remaja. Hal ini dapat dilihat dari animo para mahasiswa dalam menonton film di gedung-gedung pertunjukkan. Film mempunyai makna yang unik di antara media komunikasi lainnya. Melihat karya seni berbentuk film merupakan salah satu kajian subjektif. Hal ini sesuai apa yang disampaikan oleh (Chinita). Selain dipandang sebagai media komunikasi yang efektif dalam penyebarluasan ide dan gagasan, film juga merupakan media ekspresi seni (Tindaon) yang memberikan jalur pengungkapan kreativitas, dan media budaya yang melukiskan kehidupan manusia dan kepribadian suatu bangsa (Wulandari).

Dalam film kita bisa melihat budaya bahkan mempelajarinya, baik dalam budaya dalam negeri maupun luar negeri. Film merupakan ekspresi budaya yang digarap dengan menggunakan kaidah sinematografi dan mencerminkan budaya si pembuatnya (Irwanto et al.). Setiap budaya pasti memiliki keunikan masing-masing, terkadang sutradara secara tersirat membuat kebudayaan itu dari representasi dirinya sendiri. Unsur-unsur budaya yang ditunjukkan dalam film bisa terinspirasi dari budaya yang benar adanya maupun menciptakan budaya baru dalam pembuatan film tersebut (Tazakka et al.). (Kirkman et al.) mendefinisikan budaya sebagai pemrograman kolektif dari pikiran yang membedakan anggota satu kelompok manusia dari yang lain.

Masing-masing daerah memiliki lingkungan sosial budaya yang berpotensi untuk dijadikan sumber belajar. Sumber belajar bagi seorang guru memiliki peran yang sangat penting dalam penyusunan bahan ajar (Widodo). Kebudayaan salah satu bagian dari hal yang disenangi sebagai bahan untuk belajar. Kebudayaan merupakan segala aktivitas intelektual, spiritual, artistik, estetik, cara hidup, kepercayaan, dan kebiasaan hidup yang dilakukan oleh seseorang maupun kelompok masyarakat tertentu (Sutrisno, M., \& Putranto). Dilihat dari pendapat tersebut kebudayaan merupakan bagian yang sangat besar dan luas. Nilai budaya disebarluaskan oleh masyarakat itu sendiri melalui proses sosialisasi baik menggunakan lisan maupun tulisan. Sehingga setiap kelompok masyarakat dapat memiliki dan membentuk kebudayaan sebagai hasil kesepakatan dalam proses sosial yang berlaku pada lokalitas tertentu (Widodo).

Mengkaji nilai-nilai budaya merupakan salah satu eksistensi sebuah negara. Maka dari itu dengan mengkaji nilai-nilai budaya lokal berarti telah menjaga eksistensi bangsa itu sendiri. Hal ini dikarenakan 
puncak kebudayaan nasional merupakan akumulasi dan adaptasi dari berbagai macam nilai-nilai luhur budaya lokal kemudian diakui untuk membentuk kebudayaan. Tidak semua nilai kebudayaan berlaku benar dalam kebudayaan pada daerah lain, sehingga nilai budaya tidak bersifat universal. Sebuah kebudayaan yang baik memang seharusnya diberikan untuk peserta didik atau mahasiswa agar memberikan suatu nilainilai kehormatan yang saat ini sulit ditemukan pada peserta didik ataupun mahasiswa pada umumya. pembelajaran nilai budaya tidak semua berdasarkan dari observasi. Media saat ini sudah bisa mewakili sebagai agen distribusi paling massif yang digandrungi para remaja. Salah satunya adalah film pendek, terutama di masa pandemi seperti ini film merupakan bagian dari hal yang sangat menyenangkan untuk mengisi waktu luang.

Film pendek ialah salah satu bentuk film yang sederhana dan kompleks. Durasi film pendek biasanya di bawah 60 menit. (Erlyana and Bonjoni). Biasanya film pendek hanya berdurasi kurang dari satu jam, yang penting dalam sebuah film pendek adalah isi dari cerita film tersebut. Menggambarkan tentang apa atau cerita apa yang ingin diangkat agar dijadikan sebuah pemahaman baru dari penikmat film itu sendiri. Terdapat banyak film pendek yang menggambarkan tentang budaya Indonesia, salah satunya adalah film pendek 'Marak: Mresani Panji Sekar. Film ini adalah salah satu karya yang dibuat oleh Keraton Yogyakarta. Dengan media sosial saat ini Keraton Yogyakarta tetap mau beradaptasi dengan perkembangan zaman di bidang teknologi. Media youtube yang dimiliki selama tidak kurang tiga tahun bernama Keraton Yogyakarta mempunyai pengikut sebanyak 129.000 ini mengartikan bahwa penonton juga menikmati budaya tradisional Indonesia.

Film pendek 'Marak: Mresani Panji Sekar' yang diproduksi KHP Kridhomardowo, Tepas Tandhayekti, dan Keraton Yogyakarta. Dibuat pada tahun 2020, sebagai sutradara adalah RW. Purwoguritno, dalam kategori drama, dan untuk ditonton 13 tahun ke atas. Mengisahkan keseruan dua orang artis lokal Yogyakarta Yu Lilin (Brilliana Desy Arfira) dan Bu Siti (Siti Fauziah Saekhoni) untuk menyaksikan Beksan Panji Sekar pada Uyon-Uyon Hadiluhung. Dengan penampilan spesial dari GKR Condrokirono dan KPH Notonegoro. Bu Siti ketika sedang berada di warung bertemu dengan temannya Yu Lin yang sedang terburu-buru karena temannya ada yang sakit, kemudian Bu Siti memaksa untuk ikut ke Keraton, tetapi karena pada saat itu Bu Siti hanya menggunakan daster. Bu Siti diinstruksikan harus mengganti bajunya, karena adat Keraton tidak boleh menggunakan baju asal-asalan.

Berdasarkan penjelasan latar belakang tersebut dapat dirumuskan masalah dalam penelitian meliputi, bagaimana nilai-nilai budaya Jawa Keraton Yogyakarta serta makna yang ditampilkan dalam film 'Marak: Mresani Panji Sekar'. Agar permasalahan yang akan diteliti tidak meluas dan lebih spesifik, maka dengan ini penelitian dibatasi dari tahap mendeskripsikan, menganalisis, kemudian memaknai nilainilai budaya Jawa Keraton Yogyakarta yang terdapat dalam film. Adapun tujuan dari penelitian ini adalah mendeskripsikan nilai-nilai Jawa Keraton Yogyakarta yang ditampilkan dalam film 'Marak: Mresani Panji Sekar' serta mengungkap dan memahami makna yang terkandung dalam nilai-nilai adat tersebut, dengan cara menganalisis film 'Marak: Mresani Panji Sekar' menggunakan konsep kualitatif bersumber dari hasil pengamatan, kajian dokumen, dan dokumentasi. Hasil penelitian ini diharapkan mampu memberikan pengetahuan baru tentang kebudayaan Jawa, terutama dalam Keraton Yogyakarta, yang nantinya dapat dikaitkan dengan ilmu Bahasa dan sastra sehingga hasil-hasil yang didapatkan bermanfaat khususnya bagi mahasiswa, sesama peneliti, dan tenaga pengajar serta masyarakat secara luas.

Terdapat beberapa penelitian yang terdahulu, penelitian yang sama yang dilakukan oleh Muhammad Sulthan Tazakka, Rama Purba Dewa dan Ananda A'raaf Putro dengan judul "Representasi Nilai-Nilai Budaya Jawa pada Film (Studi Semiotika Representasi Nilai-Nilai Budaya Jawa pada Film "Mantan Manten"Karya Farishad Latjuba)". Menggunakan metode penelitian kualitatif deskriptif dengan analisis interpretatif semiotika model Roland. Penelitian ini secara langsung mengumpulkan informasi yang didapat dari objek penelitian. yakni film Mantan Manten, menganalisis aspek-aspek yang melingkupi sistem kepercayaan, sistem sosial, bahasa, kesenian, dan sebagainya, berupaya memperoleh gambaran atau pengertian yang bersifat umum dan relatif menyeluruh mencakup permasalahan yang diteliti. Penelitian kedua dilakukan oleh Yana Erlyana dan Michael Bonjoni dengan judul Perancangan Film Pendek "Tanya Sama Dengan". Permasalahan yang diangkat dalam film pendek bertujuan untuk menyadarkan dan memberikan dampak positif bagi masyarakat untuk lebih peduli terhadap pendidikan anak-anaknya. Melalui observasi, wawancara, dan penelitian studi kepustakaan dilakukan untuk mengetahui dampak dan akibat dari anak yang tidak bersekolah dan ciri ciri umum anak yang tidak mengenyam Pendidikan. Penelitian selanjutnya dilakukan oleh Kori Lilie Muslim, dalam artikel berjudul "Nilai-Nilai Islam dalam Budaya dan Kearifan Lokal (Konteks Budaya Minangkabau)" yang Dimuat dalam Jurnal 
Fuaduna. Melayu identik dengan Islam. Hal ini disebabkan karena adanya pepatah adat yang menyebutkan "Syarak mengata adat memakai", yang mengandung arti bahwa adat merupakan operasional dari nilai-nilai Islam. Di samping itu adat dalam kebudayaan Melayu bersumber dari Islam dan tidak boleh ada pertentangan adat dengan Islam, jika terdapat pertentangan maka adatlah yang mengalah. Hal ini diungkapkan dalam pepatah adat "adat bersendi syarak, syarak bersendi kitabullah" (Muslim).

Dari penelitian yang sudah dilakukan peneliti terdahulu, maka bisa dilihat bahwa belum ada yang meneliti nilai budaya suatu tempat secara khusus. Objek penelitian yang ingin penulis lakukan adalah budaya jawa Keraton Yogyakarta. Hal ini juga dapat dijadikan sebagai tauladan baik di dunia Pendidikan ataupun kebudayaan sastra pada umumnya. Oleh karena itu, peneliti tertarik untuk melakukan penelitian dengan judul "Nilai Budaya Jawa Keraton Yogyakarta dalam Film 'Marak: Mresani Panji Sekar"' semoga dapat memberikan manfaat bagi peneliti lain untuk dijadikan kajian literatur lebih banyak.

Diharapkan dengan adanya penelitian ini para peserta didik atau mahasiswa mampu untuk mempelajari dan menyerap nilai budaya sebagai implementasi di sekolah ataupun perguruan tinggi. Selain itu film juga dijadikan sebagai salah satu sarana pembelajaran yang baru agar situasi belajar menjadi lebih hidup dan tidak membosankan. Di masing-masing daerah memiliki nilai budaya yang baik dan belum tentu sama dengan daerah lain. Peran seorang Guru dan Dosen menjadi salah satu fasilitator dalam menjembatani pengetahuan peserta didik dan mahasiswanya. Seorang pendidik harus mampu membuat suasana belajar menyenangkan dan terus belajar untuk terampil dengan perkembangan zaman saat ini.

\section{Metode}

Metode penelitian yang digunakan adalah metode penelitian deskriptif kualitatif yaitu dengan mendeskripsikan hasil penelitian ke dalam bentuk paragraph. Penggunaan metode deskriptif kualitatif ini dilakukan untuk mengkaji nilai budaya jawa Keraton Yogyakarta melalui film 'Marak: Mresani Panji Sekar'. Sama dengan penelitian yang telah dilakukan oleh (Verulitasari) teknik pengumpulan data dilakukan melalui observasi, wawancara, dan studi dokumen. Namun, di sini peneliti hanya menggunakan dua teknik pengumpulan data, yaitu teknik observasi dan studi dokumen dalam Film pendek 'Marak: Mresani Panji Sekar'.

Melalui teknik studi dokumen, peneliti jadi lebih mengetahui tentang adat Keraton Yogyakarta dan perhelatan uyon-uyon. Kemudian nilai-nilai budaya yang ada pada Keraton Yogyakarta seperti apa yang sudah dikemukakan oleh (Giro) bahwa nilai-nilai budaya merupakan orientasi atau pedoman bagi manusia dalam berperilaku. Nilai-nilai budaya yang terdapat pada film 'Marak: Mresani Panji Sekar' merupakan suatu kegiatan yang biasa dilakukkan oleh Keraton Yogyakarta sehingga membentuk identitas budaya di Keraton pada khususnya.

\section{Hasil dan Diskusi}

Dengan menggunakan metode kualitatif deskriptif, peneliti menganalisis berdasarkan tujuan dari penelitian ini yaitu mendeskripsikan nilai budaya Jawa Keraton Yogyakarta yang ditampilkan dalam film 'Marak: Mresani Panji Sekar'. Untuk mencapai tujuan ini, adapun hasil yang telah dicapai selama berlangsungnya kegiatan penelitian yaitu, peneliti mengumpulkan data dengan cara mencatat hal yang terdapat di deskripsi Film pendek 'Marak: Mresani Panji Sekar' yang diproduksi KHP Kridhomardowo, Tepas Tandhayekti, dan Keraton Yogyakarta. Kemudian memilih hal yang menjadi pokok atau kunci pengambilan data. Peneliti mengambil dari studi dokumen yang diperoleh adalah waktu pembuatan yang dibuat pada tahun 2020, sebagai sutradara adalah RW. Purwoguritno, dalam kategori drama, dan untuk ditonton 13 tahun ke atas. Mengisahkan keseruan dua orang artis lokal Yogyakarta Yu Lilin (Brilliana Desy Arfira) dan Bu Siti (Siti Fauziah Saekhoni) untuk menyaksikan Beksan Panji Sekar pada Uyon-Uyon Hadiluhung. Setelah melewati beberapa proses pengumpulan data peneliti melakukan pengumpulan data dalam beberapa adegan dalam film. Kemudian yang peneliti dapatkan nilai budaya dalam adegan yang nantinya akan dideskripsikan untuk mengetahui nilai budaya Keraton Yogyakarta dalam film 'Marak: Mresani Panji Sekar'. 


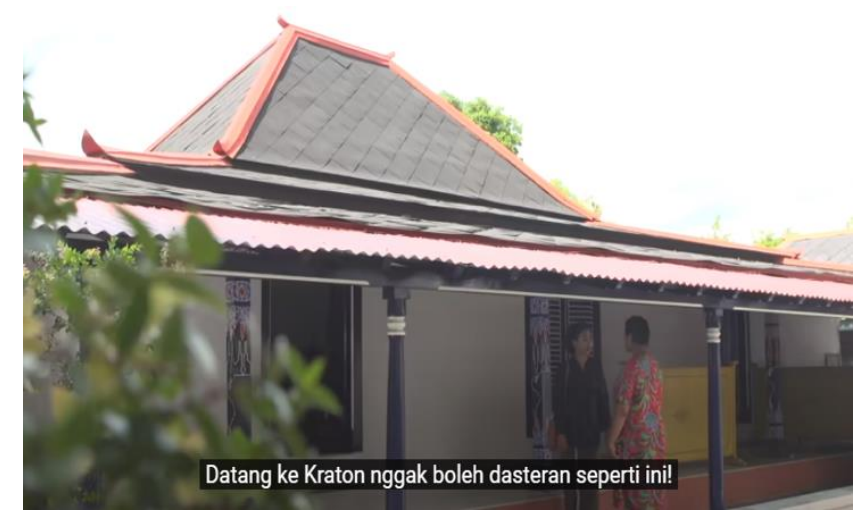

Gambar 1. Tidak Pakai Baju Asal

Pada gambar 1 di atas Yu Lin sedang menjelaskan kepada Bu Siti bahwa ketika masuk ke dalam tidak boleh pakai baju asal-asalan. Dalam gambar diperlihatkan Bu Siti menggunakan daster merah bungabunga selutut. Maka hal itu tidak perkenankan dalam adat Keraton Yogyakarta, disebut ragam busana adat abdi dalem estri adalah pakaian yang digunakan untuk abdi dalam perempuan. Abdi Dalem estri (perempuan) juga mengenakan busana adat dalam menjalankan tugas dan kewajiban untuk Keraton Yogyakarta. Busana ini memiliki beberapa ragam, baik untuk melaksanakan tugas harian maupun upacara. Masing-masing memiliki aturan baik dalam penggunaan maupun cara pemakaian.

Oleh karena itu, semua yang masuk ke Keraton tidak boleh sembarangan menggunakan pakaian, karena sudah mempunyai aturannya masing-masing. Apalagi seorang Abdi Dalam Estri yang memang mengabdi di Keraton Yogyakarta. Penggunaan pakaian sudah diatur sejak dulu. Maka dari itu nilai budayanya masih ada di sekitar Keraton sampai saat ini. Hal ini bertujuan agar para Abdi Dalam terlihat lebih rapih, sopan, dan tampil seragam.

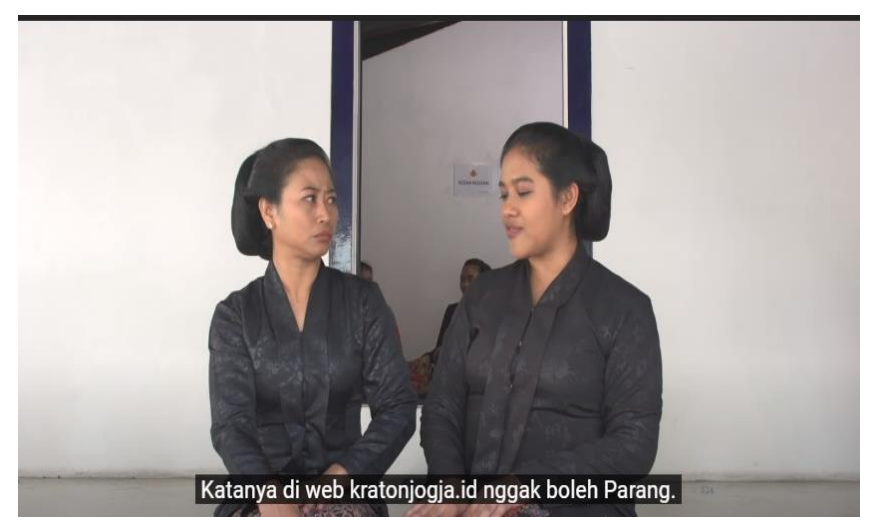

Gambar 2. Larangan Batik Parang

Pada gambar 2 diperlihatkan dialog dari Bu Siti bahwa apa yang digunakan Yu Lin (motif parang) merupakan salah satu larangan yang digunakan dalam Keraton Yogyakarta. Batik larangan Keraton Yogyakarta, atau kadang disebut Awisan Dalem, adalah motif-motif batik yang penggunaannya terikat dengan aturan-aturan tertentu di Keraton Yogyakarta dan tidak semua orang boleh memakainya. Berawal dari Batik Larangan yang hidup di Keraton dalam ritual Keprabon, berkembang luas di masyarakat pada masa kepemimpinan SriSultan Hamengkubuwono IX (Prihandayani). Keyakinan akan adanya kekuatan spiritual maupun makna filsafat yang terkandung dalam motif kain batik menjadi salah satu hal yang melatarbelakangi adanya batik larangan di Yogyakarta. Oleh karena itu beberapa motif, terutama yang memiliki nilai falsafah tinggi, dinyatakan sebagai batik larangan.

Hal ini masuk ke dalam bagian nilai budaya dalam kepercayaan, karena hal yang diyakini oleh Keraton Yogyakarta batik motif parang mampu menciptakan suasana yang religius serta memancarkan aura magis sesuai dengan makna yang dikandungnya. Motif ini mengajarkan agar sebagai manusia mempunyai watak dan perilaku yang berbudi luhur sehingga dapat mengendalikan segala godaan dan nafsu (Sutiyati). Dimaksud di sana adalah bukan maksudnya batik motif parang tidak boleh digunakan di Keraton 
Yogyakarta. Akan tetapi, menurut filosofi yang menggunakan banyak makna. Penggunaan batik parang tidak boleh digunakan untuk sembarang orang.

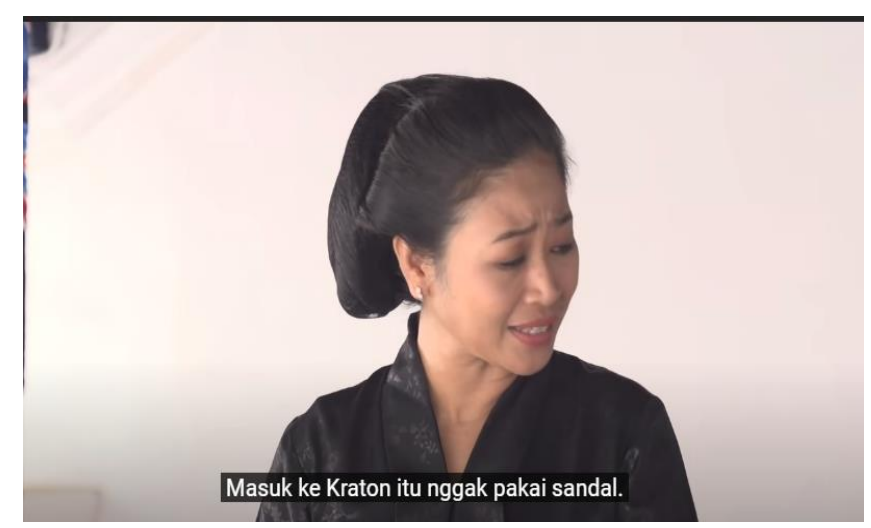

Gambar 3. Abdi Dalem Keraton Yogyakarta Nyeker

Dalam gambar 3 di sana diperlihatkan dialog bahwa Yu Lin melarang Bu Siti untuk menggunakan sandal di dalam Keraton. Nyeker merupakan istilah dalam Bahasa Jawa Ngoko yang berarti tidak memakai alas kaki. Bahwa dari pangeran sampai abdi dalem, ketika memakai peranakan (busana Karaton), tidak memakai alas kaki ketika memasuki Keraton. Dalam hal ini, nyeker di area Keraton Yogyakarta merupakan bentuk dari demokratisasi bahwa manusia itu adalah saudara dan setara. Semua manusia itu berasal dari bumi dan akan kembali ke bumi. Hal ini beranggapan nyeker sebagai tanda penghormatan dari tempat yang dianggap suci. Dalam hal ini Keraton Yogyakarta dianggap sebagai tempat yang suci.

Dalam keadaan nyeker atau tidak menggunakan alas kaki masuk ke dalam bagian nilai budaya penghormatan. Nyeker juga dilakukan untuk menghormati tempat yang dianggap suci seperti halnya ketika di masjid ada tempatnya untuk melepas sandal disebut juga dengan batas suci. Para abdi dalem itu dalam keadaan suci atau bersih dan datang dengan maksud baik ketika memasuki area Kasultanan Yogyakarta. Nyeker bukan sesuatu yang asing bagi lingkungan Keraton Yogyakarta karena setiap apa yang dilakukan di Lingkungan Keraton baik bangunan atau upacara adatnya selalu memiliki makna dibaliknya. nyeker juga dilakukan sebagai bentuk penghormatan kepada tempat yang dianggap suci seperti Karaton Yogyakarta.

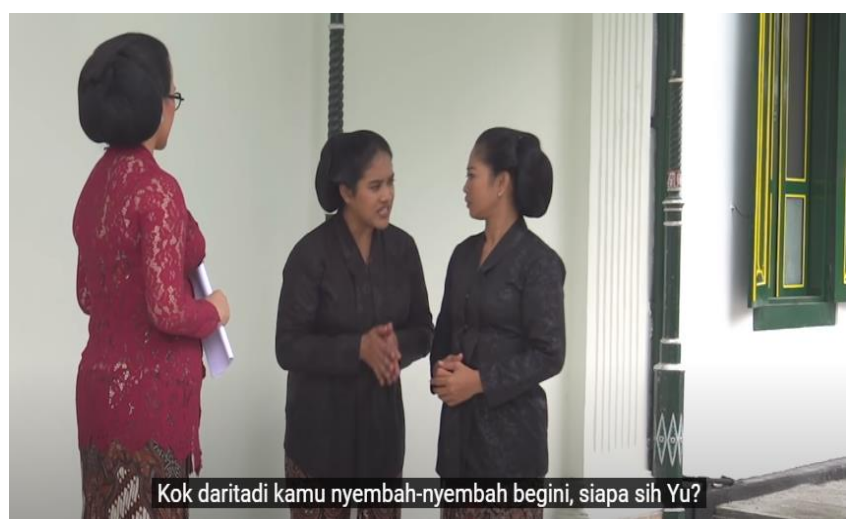

Gambar 4. Salam Hormat untuk Raja atau Ratu

Dalam gambar 4 disajikan sebuat gambaran tentang pertemuan antara Bu Siti, Yu Lin, dan Ratu. Kemudian Yu Lin menyembah kepada Ratu dan ditanyakan oleh Bu Siti untuk apa dan pada siapa penyembahan tersebut dilakukan. Memberikan salam hormat kepada Ratu hal ini disebut dengan Hormat Karna. Hormat Karna adalah tata cara penghormatan antara sultan dan adipati. Bentuknya kedua tangan diangkat ke atas sejajar kuping, mirip orang takbir saat akan menjalankan salat. Hal ini dilakukan ketika Abdi Dalem bertemu dengan Raja atau Ratu Hameng Kubuwono X.

Hormat Karna termasuk dalam kajian nilai budaya hormat, karena menerapkan rasa hormat kepada orang yang lebih tinggi jabatannya. Dalam hal ini yang disembah atau disebut Hormat Karna adalah anak dari Raja Hameng Kubuwono X. Suku Jawa dikenal memiliki prinsip hidup hormat dan rukun, yang dimaksudkan untuk menjaga keselarasan atau harmoni sosial (Etikawati et al.). Mengucapkan salam sambil Hormat Karna adalah bentuk perilaku dan merupakan adat budaya Keraton Yogyakarta yang pasti berbeda- 
beda aturannya pada Keraton lain. Hal ini sesuai dengan pendapat (Istiyanto and Novianti) Seseorang akan berperilaku sesuai latar belakang budayanya masing-masing dan akan mempunyai ciri khas yang berbeda dengan orang lain yang berbeda budaya pula.

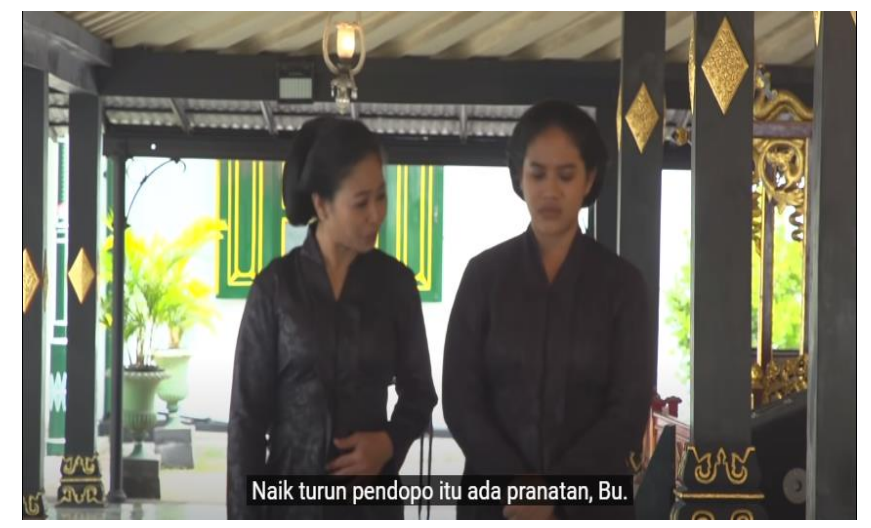

Gambar 5. Aturan dalam Keraton

Pada gambar 5 di atas diperlihatkan Yu Lin yang sedang berbicara kepada Bu Siti bagaimana cara naik turun pendopo di Keraton Yogyakarta. Hal itu disebut pranata atau aturan. Dimana jika abdi dalam akan meninggalkan tempat yang ada Raja maka harus jalan merangkak sampai tempat yang dituju dan sebelumnya tidak lupa melakukan hormat karna. Pranata adalah aturan, Di dalam sebuah pranata sosial akan ditemukan seperangkat nilai dan norma sosial yang berfungsi mengorganir (menata) aktivitas dan hubungan sosial di antara para warga masyarakat dengan suatu prosedur umum sehingga para warga masyarakat dapat melakukan kegiatan atau memenuhi kebutuhan hidupnya yang pokok (Santosa).

Dalam aturan ini yang disebut sebagai pranata atau aturan masuk bagian nilai kehormatan. Dimana seorang Abdi Dalem harus memberi salam dengan menggunakan hormat karna kemudian meninggalkan tempat dengan berjalan jongkok sampai tempat tertentu. Aturan ini dibuat untuk memperlihatkan rasa hormat dalam kebudayaan Jawa khususnya Keraton Yogyakarta. Aturan berjalan jongkok ini tidak hanya dilakukan oleh Abdi Dalem perempuan saja. Akan tetapi juga dilakukan oleh Abdi Dalem laki-laki pada saat ngin menghadap atau meninggalkan Raja Hameng Kubuwono X.

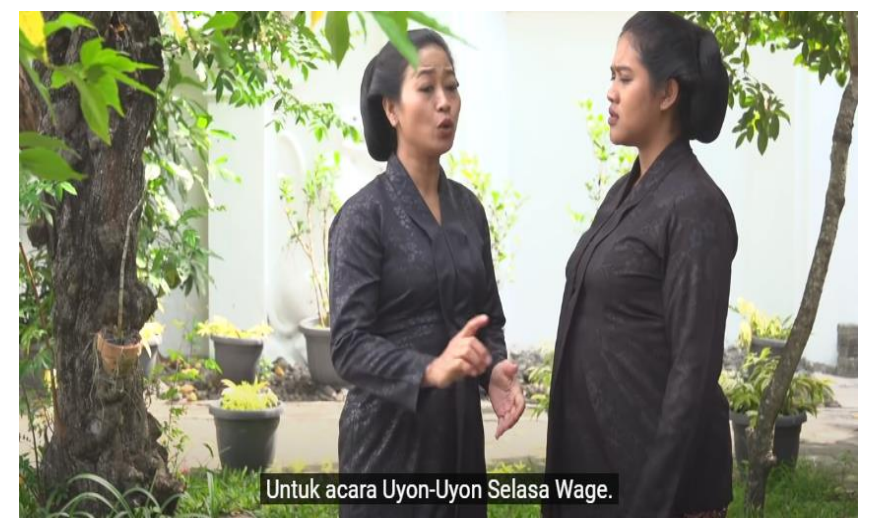

Gambar 6. Upacara Adat Uyon-Uyon

Dalam gambar 6 di atas diceritakan bahwa Yu Lin sedang menjelaskan kepada Bu Siti bahwa mereka sedang melakukan latihan untuk memperingati Upacara adat uyon-uyon. Uyon-Uyon Hadiluhung digelar untuk memperingati hari kelahiran Sri Sultan Hamengku Buwono X. Uyon-Uyon Hadiluhung sendiri diadakan sebagai upacara adat untuk memperingati kelahiran Sri Sultan Hamengku Buwono X yang jatuh pada Selasa Wage. Adapun Gendhing yang akan diputar dalam Uyon-Uyon Hadiluhung terdiri dari Gendhing Pembuka, Gendhing Soran, Bedhaya Sapta, Gendhing Lirihan I hingga III dan Gendhing Penutup. Bedhaya Sapta sendiri merupakan salah satu tarian klasik Yasan dalem Sri Sultan Hamengku Buwono IX. Sapta sendiri berarti tujuh yang merujuk pada jumlah penari.

Pada gambar upacara adat uyon-uyon ini masuk ke dalam nilai kebudayaan seni. Seni di bidang kebudayaan adalah seni yang erat hubungannya dangan nilai-nilai budaya yakni: adat-istiadat dan kepercayaan (Sudira Made Bambang Oka). Sistem nilai budaya lain yang ada relevansi dengan seni adalah 
sistem nilai budaya biasanya berfungsi sebagai pedoman tertinggi bagi tingkah laku masyarakat. Hal ini sependapat dengan pendapat (Syarifuddin) Sistem nilai budaya terdiri dari konsep yang hidup dalam alam pikiran sebagian besar warga masyarakat, sejumlah pandangan mengenai soal yang paling berharga dan bernilai dalam hidup. Sistem nilai budaya menjiwai semua pedoman yang mengatur tingkah laku warga pendukung kebudayaan. Sistem nilai budaya menjiwai semua pedoman yang mengatur tingkah laku warga pendukung kebudayaan. Sistem nilai budaya biasanya dianut oleh sebagian besar warga masyarakat.

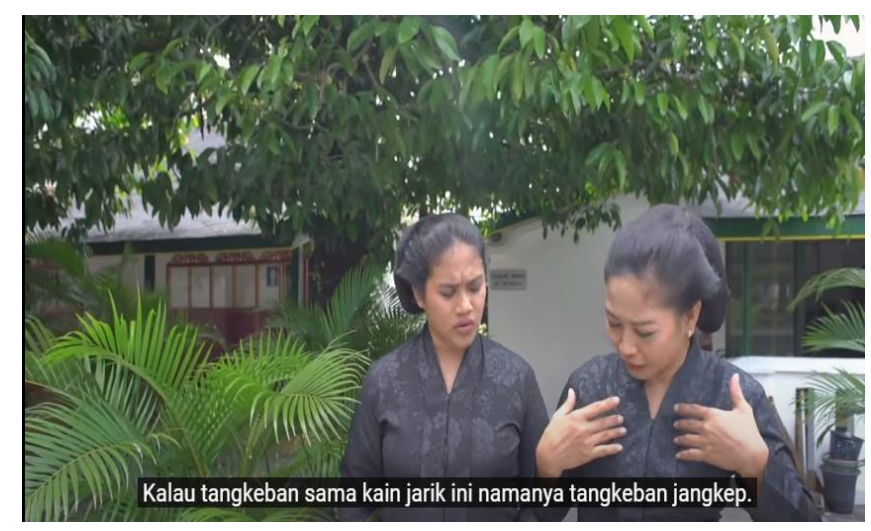

Gambar 7. Tangkeban Abdi Dalem Keraton

Pada gambar 7 di atas di jelaskan Yu Lin sedang menjelaskan kepada Bu Siti tentang pakaian yang digunakan oleh Bu Siti dan Yu Lin sekarang yaitu, penggunaan tangkeban. Tangkeban merupakan model baju kebaya tanpa bef (kutubaru). Tangkeban sering disebut juga dengan baju 'kartinian' karena wujudnya seperti kebaya yang dikenakan oleh RA Kartini. Berwarna hitam polos atau motif kembang batu, dan tidak berbahan brokat. Sebelum mengenakan tangkeban, Abdi Dalem estri juga diharuskan memakai pakaian semekan secara lengkap. Tangkeban termasuk baju Abdi Dalem yang memiliki ketentuan khusus, sehingga tidak semua diperkenankan memakainya. Yang diperbolehkan mengenakan tangkeban adalah Abdi Dalem estri golongan keprajan yang berada di tepas dan masih memiliki kedudukan Darah Dalem, tanpa minimal pangkat.

Dalam penggunaan tangkeban ini mengandung nilai kebudayaan sopan santun. Hal ini dikarenakan penggunaan masing-masing pakaian yang dipakai oleh Abdi Dalem estri merupakan keharusan dan penanda sesorang dalam menjalankan tugasnya. Pakaian digunakan sebagai salah satu cara untuk menutup aurat wanita dan salah satunya tangkeban, yang dinilai lebih sopan dibandingkan dengan pakaian Abdi Dalem estri yang lain. (Siregar) mengatakan bahwa nilai-nilai budaya merupakan nilai-nilai yang disepakati dan tertanam dalam suatu masyarakat, lingkup organisasi, lingkungan masyarakat, yang mengakar pada suatu kebiasaan, kepercayaan (believe), simbol-simbol, dengan karakteristik tertentu yang dapat dibedakan 1 dan lainnya sebagai acuan prilaku dan tanggapan atas apa yg akan terjadi/ sedang terjadi. Sopan santun bisa dianggap sebagai norma tidak tertulis yang mengatur bagaimana seharusnya kita bersikap atau berperilaku (Suryani).

\section{Simpulan}

Mengkaji nilai-nilai budaya lokal berarti telah menjaga eksistensi bangsa itu sendiri. Dalam penelitian ini bertujuan untuk mendeskripsikan nilai-nilai budaya. Hasil yang dicapai pada penelitian ini, dapat disimpulkan dimana saat pemeran dalam film 'Marak: Mresani Panji Sekar' tersebut berada di lokasi/setting di dalam Keraton Yogyakarta, adegan tersebut sudah memenuhi kriteria yang layak untuk dianalisis karena dalam gambar tersebut mengandung nilai budaya Keraton Yogyakarta. Pada Sembilan adegan di atas terdapat nilai-nilai budaya Jawa Keraton Yogyakarta, seperti rasa hormat dari abdi dalem kepada keluarga Raja Hamengkubwono X, melalui adegan sungkem, rasa sopan santun dari seorang abdi kepada keluarganya Raja Hamengkubwono X, nilai rasa syukur kepada nikmat yang diberikan oleh tuhan, dan rasa tanggung jawab, seperti menjalankan aturan yang sudah disepakati. Kesemuanya ditujukan untuk menjaga keharmonisan tatanan aturan-aturan yang sudah ada sejak dulu. 


\section{Ucapan Terima Kasih}

Terima kasih kepada Film pendek 'Marak: Mresani Panji Sekar' sebagai sumber data dalam penelitian ini. Kepada Tim Jurnal Hortatori yang memberikan kesempatan sampai dengan artikel ini terbit. Tidak lupa juga terima kasih kepada semua pihak yang tidak dapat kami sebutkan satu persatu yang telah berkontribusi dalam penelitian hingga pembuatan artikel ini.

\section{Daftar Rujukan}

Chinita, Fátima. "Positioning Art Cinema: Film and Cultural Value, by Geoff King." Alphaville: Journal of Film and Screen Media, no. 20 (2021): 265-269. Web.

Erlyana, Yana, and Michael Bonjoni. "Perancangan Film Pendek 'Tanya Sama Dengan." Jurnal Rupa Rupa Program Studi Desain Komunikasi Visual Universitas Bunda Mulia, vol. 3, no. 2 (2014): 129-138. Web.

Etikawati, A. I., et al. "Pengembangan Instrumen Pengasuhan Berbasis Nilai Budaya Jawa." Jurnal Ilmu Keluarga Dan Konsumen, vol. 12, no. 3 (2019): 208-222. Web.

Febriyanti, Rina Husnaini, et al. "Absurdity In The Novel Perburuan By Pramoedya Ananta Toer: Existentialism Study." Hortatori : Jurnal Pendidikan Bahasa Dan Sastra Indonesia, vol. 4, no. 1 (2020): 40-47. Web.

Giro, Ramot Silalahi. Fungsi Keluarga Dalam Penanaman Nilai-Nilai Budaya Masyarakat Minangkabau Di Kota Bukit Tinggi. Departemen Pendidikan Nasional, (2001). Web.

Irwanto, B., et al. "Finite Element Model Updating in the Vibration of Bladed Disk - Shaft Assemblies." Proceedings of the ASME Turbo Expo 2004, vol. 6 (2004): 217-225. Web.

Istiyanto, S. Bekti, and Wiwik Novianti. "Etnografi Komunikasi Komunitas Yang Kehilangan Identitas Sosial Dan Budaya Di Kabupaten Cilacap.” Jurnal Kajian Komunikasi, vol. 6, no. 1 (2018): 64-77. Web.

Kirkman, Bradley L., et al. "A Quarter Century of Culture's Consequences: A Review of Empirical Research Incorporating Hofstede's Cultural Values Framework.” Journal of International Business Studies, vol. 37, no. 3 (2006): 285-320. Web.

Kridalaksana, H. Kamus Linguistik (Edisi Keempat). Gramedia Pustaka Utama, 2013.

Mirnawati, Mirnawati. "Analisis Semiotika dalam Teks Al-Barzanji." 'A Jamiy : Jurnal Bahasa dan Sastra Arab, vol. 8, no. 1 (2019): 31-52. Web.

Muslim, Kori Lilie. "Nilai-Nilai Islam dalam Budaya dan Kearifan Lokal (Konteks Budaya Minangkabau)." Jurnal Fuaduna: Jurnal Kajian Keagamaan dan Kemasyarakatan, vol. 1, no. 1, (2018): 48-57. Web.

Pradopo, Racmad Djoko. Kritik Sastra Modern. Gama Media, 2002.

Prihandayani, Annita Komarianti. "Transformasi Sinjang Batik Parang Rusak dan Parang Barong Yogyakarta dari Seni Motif ' Geometris ’ Menjadi Seni Motif Abstrak.”Wacadesain, vol. 1, no. 1 (2020): 48-62. Web.

Santosa, Agus. "Pranata Sosial: Pengertian, Tipe Dan Fungsi." Pendidikan Sosiologi, vol. 1, (2009) pp. 123. Web.

Siregar, Fitri Rayani. "Nilai-Nilai Budaya Sekolah dalam Pembinaan Aktivitas Keagamaan Siswa SD IT Bunayya Padangsidimpuan." Jurnal Kajian Gender Dan Anak, vol. 1, no. 1, (2018): 1-11. Web.

Sudira Made Bambang Oka. Ilmu Seni. Inti Prima, 2010.

Suryani, Lilik. "Upaya Meningkatkan Sopan Santun Berbicara dengan Teman Sebaya Melalui Bimbingan Kelompok." E-Jurnalmitrapendidikan.Com, vol. 1 (2017): 112-124. Web.

Sutiyati, Endang. "NILAI FILOSOFI MOTIF PARANG RUSAK GURDO DALAM TARI BEDHAYA HARJUNA WIWAHA." Imaji, vol. 14, no. 1 (2016): 12-20.

Sutrisno, M., \& Putranto, H. Teori-Teori Kebudayaan. Kanisius, 2005.

Syarifuddin, Didin. "Nilai Wisata Budaya Seni Pertunjukan Saung Angklung Udjo Kota Bandung, Jawa Barat, Indonesia." Jurnal Manajemen Resort Dan Leisure, vol. 13, no. 2 (2017): 53-60. Web.

Tazakka, Muhammad Sulthan, et al. "Representasi Nilai-Nilai Budaya Jawa Pada Film (Studi Semiotika Representasi Nilai-Nilai Budaya Jawa Pada Film 'Mantan Manten' Karya Farishad Latjuba)." Syntax Literate; Jurnal Ilmiah Indonesia, vol. 5, no. 4 (2020): 161-177. Web. 
Teeuw. A. Sastra Dan Ilmu Sastra: Pengantar Teori Sastra. Pustaka Jaya, 1988.

Tindaon, Yosi Abdian. "Pembelajaran Sastra Sebagai Salah Satu Wujud Implementasi Pendidikan Berkarakter." Journal of Chemical Information and Modeling, vol. 1, no. 9 (2012): 1689-1699. Web.

Verulitasari, Esti. "Nilai Budaya Dalam Pertunjukan Rapai Geleng Mencerminkan Identitas Budaya Aceh." Catharsis : Journal of Arts Education, vol. 5, no. 1 (2016): 41-47. Web.

Widodo, Arif. "Nilai Budaya Ritual Perang Topat sebagai Sumber Pembelajaran IPS Berbasis Kearifan Lokal di Sekolah Dasar." Gulawentah:Jurnal Studi Sosial, vol. 5, no. 1 (2020): 1-16. Web.

Wulandari, Raras Arum. "Gambaran Nilai Budaya dan Kearifan Lokal dalam Film Wood Job!" Jurnal Ilmiah Komunikasi Makna, vol. 7, no. 2 (2019): 79-96. Web. 